Univerzitet u Beogradu
Poljoprivredni fakultet
Institut za poljoprivrednu tehniku
Naučni časopis
POLJOPRIVREDNA TEHNIKA
Godina XLVI
Broj 3., 2021.
Strane: $74-88$

\title{
EFFECTS OF PRETREATMENT AND DRYING TEMPERATURE ON ANTIOXIDANTS AND ANTINUTRIENTS OF Justicia insularis AND Jatropha tanjorensis LEAVES
}

\author{
Akpan Mfrekemfon Godswill ${ }^{* 1}$, Assian Ubong Edet ${ }^{1}$, Ikrang Elijah Gorge ${ }^{1}$ \\ ${ }^{l}$ Department of Agricultural and Food Engineering, Faculty of Engineering, \\ University of Uyo, Uyo, P. M. B. 1017, Akwa Ibom State, Nigeria
}

\begin{abstract}
Antioxidants and antinutrient contents of leafy vegetables may be influenced by post-harvest processing. The present study was carried out to assess the effect of pretreatments $(\mathrm{P})$ and drying temperatures $(\mathrm{T})$ on antioxidants and antinutrients of Justicia insularis and Jatropha tanjorensis leaves. Four groups of samples were prepared, namely: fresh sample (FR), un-blanched and dried sample (UB), sample blanched in hot water and dried (BHW) and sample blanched in salt water and dried (BSW). Drying was conducted at $40{ }^{0} \mathrm{C}, 50{ }^{0} \mathrm{C}$ and $60{ }^{0} \mathrm{C}$ using hot air oven. Antioxidants and antinutrients of the samples were determined. The data collected were subjected to a two-way Analysis of Variance (ANOVA) as well as Dunnett t-test at 5\% probability level. Based on the results, BHW between $50^{\circ} \mathrm{C}$ and $60^{\circ} \mathrm{C}$ increased the antioxidant activity in both vegetables. BHW $60{ }^{\circ} \mathrm{C}$ was able to reduce oxalate and phytate contents to reasonable level while BSW50 ${ }^{0} \mathrm{C}$ drastically decreased hydrogen cyanide and tannin contents. However, the overall, individualistic, and interactive effects of $\mathrm{P}$ and $\mathrm{T}$ had significant $\left(\mathrm{P}_{\mathrm{cal}}<0.05\right)$ influence on majority of antioxidant activity and antinutrient contents in both vegetables.
\end{abstract}

Key words: Justicia insularis, Jatropha tanjorensis, pretreatment, drying temperature, antioxidants, antinutrients

\footnotetext{
${ }^{*}$ Corresponding Author. E-mail address: mfrekemfongakpan@uniuyo.edu.ng
} 


\section{INTRODUCTION}

Vegetables are succulent part(s) of plant which could be eaten raw, cooked with other dishes, as an appetizer or salad [1]. Some of them include pumpkin, cabbage, carrot, garden egg, Justicia insularis and Jatropha tanjorensis, etc. They are key ingredients in many processed foods and pharmaceutical products [2]. Justicia insularis, commonly called "hunter's weed" is an herb of the family Acanthaceae with angular stem, and swollen aerial root at basal part of the stem [3]. The leaves are used as food ingredient especially for infants and as healing balm in some parts of West Africa [4]. Similarly, Jatropha tanjorensis, otherwise known as "hospital-too-far", belongs to the family of Euphorbiacea and is widely grown in the tropics [5]. The leaves are used as food ingredient and also employed in the traditional treatment of many diseases such as anaemia, diabetes and cardiovascular diseases [4]. Both vegetables contain essential food nutrients such as vitamins, minerals, fibre, carbohydrate, protein, natural antioxidants as well as traces of antinutrients [6,4,5]. However, antioxidants are free radical scavengers (e.g. carotenoids, folic acid, tocopherols, phenolic compounds, etc) that protect the harmful effects of reactive oxygen species such as hydroxyl radicals and peroxides [7]. Excess of these free radicals in the human body can lead to development of chronic diseases such as cancer, arteriosclerosis, nephritis, diabetes mellitus, etc [8]. Hence, natural antioxidants play a vital role in maintaining and preserving good health [9]. Conversely, antinutrients are natural or synthetic compounds found in a variety of plants that can inhibit the absorption of food nutrients in humans [10], e.g. oxalate, hydrogen cyanide, tannin, phytate, saponins, flavonoid, alkaloids, amongst others. Since both vegetables are perishable and the nutritional contents are very essential, preservation of the plant leaves is necessary. Several methods of preserving vegetables in terms of antioxidant retention or increase and reduction of antinutrients to minute level have been reported [11, 12, 13]. It has been found that pretreatment methods (e.g. blanching, cooking, boiling, etc.), blanching time, drying temperature could significantly affect antioxidants and antinutrients in fruits and vegetables $[14,15,16 ; 17,18,19,20,21]$. In an effort to preserve or retain antioxidant contents, and to reduce antinutrients to safe level, it was necessary to investigate the most suitable pretreatment and drying temperature combination that will give the product the desired quality. However, in this study the antioxidants considered were phenolic compounds while that of antinutrients were oxalate, hydrogen cyanide, tannin and phytate. The major objective of this study is to evaluate the effects of processing temperature and pretreatments on antioxidant and antinutrient content of Justicia insularis and Jatropha tanjorensis leaves.

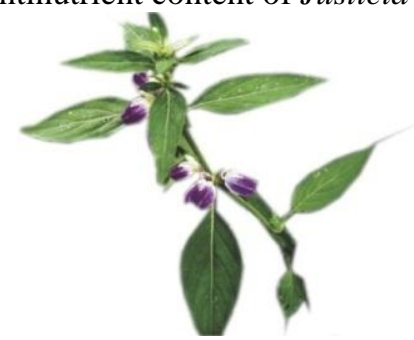

Fig. 1. Justicia insularis plant

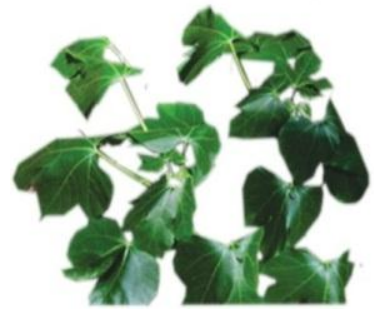

Fig. 2. Jatropha tanjorensis plant 


\section{MATERIAL AND METHODS}

\section{Preparation of Fresh and Dried Samples}

About 200 g each of Justicia insularis and Jatropha tanjorensis leaves were sourced from a local farmer in Uyo, Akwa Ibom State. The leaves were carefully washed with distilled water to remove the dirt, and wiped with a lint free towel. They were divided into four groups, namely group I, II, III and IV. Group I was regarded as fresh sample. Group II was blanched in hot water where it was placed in a sieve and immersed in a thermostatic water bath at $95{ }^{0} \mathrm{C}$ for 2 minutes. The samples were then subjected to running water at $4{ }^{0} \mathrm{C}$ for 2 minutes. They were later exposed to air for 20 minutes and wiped with a lint free towel. Group III was blanched in $10 \%$ brine solution and followed by the same procedures carried out in Group II. Group IV was untreated. Each of the group was divided into three (3) sets before subjected to oven drying using a hot air dryer Genlab model DC 125 in Food Engineering Laboratory, University of Uyo, Uyo, Nigeria, at temperature of $40^{\circ} \mathrm{C}, 50^{\circ} \mathrm{C}$ and $60^{\circ} \mathrm{C}$, respectively in duplicate. The range of temperature and brine solution used in this experiment was as found in literature [22, 23]. Each dried sample was ground into powder, bottled and labelled and was used for analysis.

\section{Preparation of Sample Extract}

The mixture of the sample $(3.0 \mathrm{~g})$ and $20 \mathrm{ml}$ of $95 \%$ ethanol was mechanically shaken for 2 hours (Griffin Flash shaker, London) and centrifuged at 3,650 rpm for 35 minutes at $4{ }^{\circ} \mathrm{C}$ (Anke DL-6000 B, China). The residue was re-extracted under the same conditions and both supernatants were collected and adjusted to $40 \mathrm{ml}$ with $95 \%$ ethanol. All extracts were filtered through Whatman $\mathrm{N}^{\circ} 1$ filter paper and stored at $4^{\circ} \mathrm{C}$ until analysis, [24].

\section{Determination of Antioxidant Activity}

The antioxidant activity was assessed using the following assays

\section{Determination of Total Phenolic Content (TPC)}

Total phenolic content (TPC) was determined using the procedure described by Bakar, Mohamed, Rahmat \& Fry, [25]. Folin-Ciocalteu reagent $(2.25 \mathrm{ml})$ was diluted ten-fold with distilled water and the extract $(300 \mu \mathrm{l})$ added. $\mathrm{Na}_{2} \mathrm{CO}_{3}$ solution $(2.25 \mathrm{ml})$ was mixed with the set up and was allowed to react for 5 mins at room temperature. After incubation for 90 mins at room temperature, absorbance was read at $725 \mathrm{~nm}$ using spectrophotometer. The concentration was expressed as $\mathrm{mg}$ gallic acid equivalents in $1 \mathrm{~g}$ of dried sample (mg GAE/g db). 


\section{Determination of 2, 2-Diphenyl-1-Picryl Hyrazyl (DPPH) Radical Scavenging Activity}

The DPPH radical scavenging activity was determined based on the method described by Gulluce, Sahin, Sokmen, Ozer, Daferera, Sokmen, Polissiou, Adiguzel \& Ozkan, [26].

A mixture of aqueous sample extract $(0.1 \mathrm{ml})$ and $0.004 \%$ methanolic solution of DPPH $(3 \mathrm{ml})$, was prepared. Absorbance of the mixture was read at $517 \mathrm{~nm}$ after 30 mins using spectrophotometer. The capacity to scavenge the DPPH radical was found using Equation 1:

DPPH scavenging activity $(\%)=\left(\frac{A_{w}-A_{e}}{A_{w}}\right) \times 100$

where $\mathrm{A}_{\mathrm{w}}=$ absorbance without extract and $\mathrm{A}_{\mathrm{e}}=$ absorbance with extract.

\section{Determination of Cupric Ion Reducing Antioxidant Capacity (CUPRAC)}

CUPRAC was determined using the method described by Sethi, Joshi, Arora, Bhowmik, Sharma \& Kumar, [27]. A mixture of sample extract $(0.1 \mathrm{ml})$ and distilled water $(1 \mathrm{ml})$ was made. This was followed by addition of $\mathrm{CuCl}_{2}$, neocuproine and ammonium acetate buffer $(\mathrm{pH} 7)\left(\mathrm{CH}_{3} \mathrm{COONH}_{4}\right)$ solution in 1:1:1 to obtain total reaction mixture of $4.1 \mathrm{ml}$. After 30 minutes of incubation at room temperature, absorbance was read at $450 \mathrm{~nm}$ using spectrophotometer. The result was expressed as $\mu \mathrm{mol}$ Trolox / g dry sample.

\section{Determination of Ferric Reducing/Antioxidant Power (FRAP)}

FRAP was determined using the method described by Butsat and Siriamornpun [28]. The FRAP solution is a mixture of $10 \mathrm{mM}$ tripyridyltriazine solution, $40 \mathrm{mM} \mathrm{HCl}, 20$ $\mathrm{mM} \mathrm{FeCl}_{3}$ solution, $300 \mathrm{mM}$ acetate buffer and $\mathrm{pH}$ 3.6. The fresh solution was heated to $37^{\circ} \mathrm{C}$ before use. A mixture of $100 \mu \mathrm{l}$ of sample extract $(100 \mu \mathrm{l})$ and FRAP solution (1.9 $\mathrm{ml}$ ) was prepared. The absorbance of the mixture was read at $593 \mathrm{~nm}$ after 60 mins using spectrophotometer. The concentration of the sample was extrapolated from the standard curve prepared with known concentrations of $\mathrm{FeSO}_{4}$ in $\mu$ mol $\mathrm{FeSO}_{4} / \mathrm{g}$ dry sample.

\section{Determination of Antinutrients}

The following antinutrients were determined:

\section{Determination of Oxalate Content}

The oxalate content of the ground sample was determined using titration method as described by Association of Official and Analytical Chemists [AOAC] [29].

A mixture of ground sample $(5 \mathrm{~g})$, distilled water $(95 \mathrm{ml})$ and $5.0 \mathrm{ml} 6 \mathrm{~N} \mathrm{HCl}$ in a beaker was heated in a water bath at $50{ }^{\circ} \mathrm{C}$ for 2 hours. Then, distilled water $(126 \mathrm{ml})$ was added to the digest. The filtrate $(50 \mathrm{ml})$ with methyl red indicator (few drops) in a beaker was evaporated. Ammonium hydroxide $(5 \mathrm{ml})$ was added to the resulting filtrate, and heated to $90{ }^{\circ} \mathrm{C}$, while $5 \%$ calcium chloride $(10 \mathrm{ml})$ solution was added, stirred and kept overnight at $5{ }^{0} \mathrm{C}$. The precipitate obtained from centrifugation and filtration was washed with $10 \mathrm{ml}$ of $20 \% \mathrm{v} / \mathrm{v} \mathrm{H}_{2} \mathrm{SO}_{4}$ and diluted with $125 \mathrm{ml}$ distilled water. 
Finally, aliquot solution $(125 \mathrm{ml})$ was heated and titrated against $0.05 \mathrm{~N}$ standardized $\mathrm{KMnO}_{4}$ solution to a faint pink colour.

\section{Determination of Hydrogen cyanide $(\mathrm{HCN})$}

Hydrogen cyanide in the ground sample was determined using alkaline picrate method (Nwokoro, Ogbonna \& Okpala [30]. The mixture of ground sample (5 g) and in $50 \mathrm{ml}$ distilled water in conical flask was corked, and the extract left overnight and later filtered.

Different concentrations of $\mathrm{KCN}$ solution containing 5 - $50 \mathrm{mg}$ cyanide and $1 \mathrm{~N} \mathrm{HCl}$ $(25 \mathrm{ml})$ were used to prepare cyanide standard curve. A mixture of filtrate $(1 \mathrm{ml})$ and alkaline picrate $(4 \mathrm{ml})$ in a test tube was incubated in a bath for 15 minutes to develop reddish brown colour. The absorbance was read using spectrophotometer at $490 \mathrm{~nm}$. The blank absorbance containing only $1.0 \mathrm{ml}$ distilled water and $4.0 \mathrm{ml}$ alkaline picrate solution was also read. The hydrocyanide content was extrapolated from the standard cyanide curve and expressed in $\mathrm{mg} / 100 \mathrm{~g}$ dry sample.

\section{Determination of Tannin}

The tannin content was determined using Folin Denis Reagent as described by Makkar, Blummel, Borowy \& Becker [31]. Furthermore, a mixture of ground sample (2 g) and $70 \%$ acetone $(10 \mathrm{ml})$ in a corked bottle was placed in ice bath centrifuge at $4{ }^{\circ} \mathrm{C}$ for $6 \mathrm{~min}$. The $0.2 \mathrm{ml}$ of cold -stored supernatant solution was pipetted into distilled water $(0.8 \mathrm{ml})$. Standard solution of tannin acid $\left(\mathrm{C}_{76} \mathrm{H}_{52} \mathrm{O}_{46}\right)$ was also prepared. Folin reagent $(0.5 \mathrm{ml})$ was added to both sample and standard followed by $20 \% \mathrm{Na}_{2} \mathrm{CO}_{3}(2.5$ $\mathrm{ml})$. The solution was incubated at room temperature for 40 minutes. Then, the absorbance was read at $725 \mathrm{~nm}$. The concentration of tannin was estimated from the standard tannic acid curve and expressed in $\mathrm{mg} / 100 \mathrm{~g}$ dry sample.

\section{Determination of Phytate Content}

Phytate content was determined using the method described by AOAC [29]. Moreover, a mixture of finely ground sample $(2.0 \mathrm{~g})$ and $0.2 \mathrm{~N} \mathrm{HCl}(20 \mathrm{ml})$ was filtered. The mixture of filtrate $(0.5 \mathrm{ml})$ and ferric ammonium iron (III) sulphate $(1 \mathrm{ml})$ solution in a test tube was boiled in a water bath for 30 minutes, cooled and centrifuged. The supernatant $(1.0 \mathrm{ml})$ was mixed with 2, 2-bipyridine $\left(\mathrm{C}_{10} \mathrm{H}_{8} \mathrm{~N}_{2}\right)$ solution $(1.5 \mathrm{ml})$ and the absorbance measured using spectrophotometer at $519 \mathrm{~nm}$. The concentration of phytate was obtained by extrapolation from a standard curve prepared from standard phytic acid $\left(\mathrm{C}_{6} \mathrm{H}_{18} \mathrm{O}_{24} \mathrm{P}_{6}\right)$ solution, and expressed in $\mathrm{mg} / 100 \mathrm{~g}$ dry sample.

\section{Statistical Analysis}

Data were collected in duplicate, Analysis of Variance (ANOVA) and Dunnett t-test done using Statistical Package for Social Scientists (SPSS) version 20 at 5\% probability level was used to assess significant mean difference (MD) between the control (fresh) and pretreatments. The results were presented in bar charts, tables, mean, standard deviation and coefficient of determination. 


\section{RESULTS AND DISCUSSION}

\section{Antioxidant Activity}

The summary and multiple comparisons of antioxidant activity of fresh leaves with pretreated and dried leaves are presented in Table 1.

Table 1. Summary and multiple comparisons of mean value of antioxidant activity of Justicia insularis and Jatropha tanjorensis fresh leaves with their mean values at different pretreatments and drying temperatures

\begin{tabular}{|c|c|c|c|c|c|}
\hline & & \multicolumn{4}{|c|}{ Justicia insularis } \\
\cline { 3 - 6 } P & $\begin{array}{c}\mathrm{T} \\
\left({ }^{\mathrm{C}} \mathrm{C}\right)\end{array}$ & $\begin{array}{c}\text { TPC } \\
(\mathrm{mg} \mathrm{GAE} / \mathrm{g} \mathrm{db})\end{array}$ & $\begin{array}{c}\text { DPPH } \\
(\%)\end{array}$ & $\begin{array}{c}\text { CUPRAC }(\mu \\
\text { mol Trolox } / \mathrm{g} \mathrm{db})\end{array}$ & $\begin{array}{c}\text { FRAP }(\mu \mathrm{mol} \\
\left.\text { FeSO }_{4} / \mathrm{g} \mathrm{db}\right)\end{array}$ \\
\hline FR & & $9.81 \pm 0.03^{\mathrm{j}}$ & $29.20 \pm 0.11^{\mathrm{a}}$ & $185 \pm 8.49^{\mathrm{c}}$ & $260 \pm 14.14^{\mathrm{d}}$ \\
\hline & 40 & $8.62 \pm 0.01^{\mathrm{a}}$ & $31.45 \pm 0.35^{\mathrm{b}}$ & $212 \pm 32.83^{\mathrm{d}}$ & $280 \pm 7.07^{\mathrm{e}}$ \\
UB & 50 & $9.07 \pm 0.03^{\mathrm{b}}$ & $32.25 \pm 0.21^{\mathrm{c}}$ & $267 \pm 4.24^{\mathrm{e}}$ & $308 \pm 5.66^{\mathrm{f}}$ \\
& 60 & $8.47 \pm 0.01^{\mathrm{c}}$ & $31.15 \pm 0.07^{\mathrm{d}}$ & $280 \pm 5.66^{\mathrm{f}}$ & $312 \pm 2.83^{\mathrm{g}}$ \\
\hline & 40 & $9.94 \pm 0.02^{\mathrm{d}}$ & $30.23 \pm 0.08^{\mathrm{e}}$ & $345 \pm 7.07^{\mathrm{g}}$ & $331 \pm 4.24^{\mathrm{h}}$ \\
BHW & 50 & $9.98 \pm 0.04^{\mathrm{e}}$ & $34.70 \pm 0.14^{\mathrm{f}}$ & $481 \pm 2.83^{\mathrm{h}}$ & $355 \pm 32.83^{\mathrm{i}}$ \\
& 60 & $8.65 \pm 0.03^{\mathrm{f}}$ & $30.30 \pm 0.21^{\mathrm{g}}$ & $492 \pm 4.28^{\mathrm{i}}$ & $353 \pm 4.24^{\mathrm{j}}$ \\
\hline & 40 & $8.29 \pm 0.03^{\mathrm{g}}$ & $28.40 \pm 0.04^{\mathrm{h}}$ & $181 \pm 2.83^{\mathrm{c}}$ & $234 \pm 1.41^{\mathrm{k}}$ \\
BSW & 50 & $7.18 \pm 0.01^{\mathrm{h}}$ & $27.60 \pm 0.42^{\mathrm{i}}$ & $235 \pm 1.48^{\mathrm{j}}$ & $247 \pm 4.95^{\mathrm{d}}$ \\
& 60 & $7.16 \pm 0.03^{\mathrm{i}}$ & $27.30 \pm 0.28^{\mathrm{j}}$ & $223 \pm 3.5^{\mathrm{k}}$ & $258 \pm 2.47^{\mathrm{d}}$ \\
\hline & & \multicolumn{5}{|c|}{ Jatropha tanjorensis $^{\mathrm{a}}$} & \\
\hline FR & & $7.81 \pm 0.03^{\mathrm{g}}$ & $18.25 \pm 0.35^{\mathrm{a}}$ & $255 \pm 5.66^{\mathrm{a}}$ & $311 \pm 11.31^{\mathrm{c}}$ \\
\hline & 40 & $7.35 \pm 0.04^{\mathrm{a}}$ & $19.10 \pm 0.14^{\mathrm{b}}$ & $379 \pm 7.07^{\mathrm{b}}$ & $330 \pm 4.24^{\mathrm{d}}$ \\
UB & 50 & $8.02 \pm 0.08^{\mathrm{g}}$ & $20.20 \pm 0.06^{\mathrm{c}}$ & $387 \pm 2.83^{\mathrm{c}}$ & $340 \pm 43.54^{\mathrm{e}}$ \\
& 60 & $7.89 \pm 0.01^{\mathrm{g}}$ & $19.30 \pm 0.04^{\mathrm{d}}$ & $383 \pm 4.24^{\mathrm{d}}$ & $421 \pm 1.41^{\mathrm{f}}$ \\
\hline \multirow{3}{*}{ BHW } & 40 & $8.96 \pm 0.01^{\mathrm{b}}$ & $20.30 \pm 0.01^{\mathrm{e}}$ & $398 \pm 1.41^{\mathrm{e}}$ & $356 \pm 4.95^{\mathrm{g}}$ \\
& 50 & $8.97 \pm 0.02^{\mathrm{c}}$ & $22.40 \pm 0.05^{\mathrm{f}}$ & $403 \pm 4.24^{\mathrm{f}}$ & $444 \pm 5.66^{\mathrm{h}}$ \\
& 60 & $9.97 \pm 0.02^{\mathrm{d}}$ & $21.50 \pm 0.14^{\mathrm{g}}$ & $412 \pm 8.49^{\mathrm{g}}$ & $546 \pm 2.83^{\mathrm{i}}$ \\
\hline & 40 & $7.75 \pm 0.07^{\mathrm{g}}$ & $17.50 \pm 0.07^{\mathrm{h}}$ & $269 \pm 1.41^{\mathrm{a}}$ & $300 \pm 2.83^{\mathrm{c}}$ \\
BSW & 50 & $7.55 \pm 0.16^{\mathrm{e}}$ & $17.80 \pm 0.05^{\mathrm{i}}$ & $302 \pm 2.12^{\mathrm{h}}$ & $410 \pm 7.07^{\mathrm{j}}$ \\
& 60 & $6.97 \pm 0.04^{\mathrm{f}}$ & $16.40 \pm 0.06^{\mathrm{j}}$ & $293 \pm 0.71^{\mathrm{i}}$ & $434 \pm 1.41^{\mathrm{k}}$ \\
\hline
\end{tabular}

Note: $\mathrm{P}=$ pretreatment, $\mathrm{T}=$ temperature $\left({ }^{0} \mathrm{C}\right), \mathrm{FR}=$ fresh sample, $\mathrm{UB}=$ un-blanched and dried sample, $\mathrm{BHW}=$ sample blanched in hot water and dried, and BSW=sample blanched in salt water and dried. All data are the mean \pm standard deviation of duplicate. Mean with the same superscript in the same column are statistically the same as the fresh sample (ANOVA, $\mathrm{P}_{\mathrm{tab}}<0.05$, Dunnette $\mathrm{t}$-test).

From Table 1., the fresh samples of Justicia insularis and Jatropha tanjorensis leaves contained 9.81 and $7.81 \mathrm{mg} \mathrm{GAE} / \mathrm{g} \mathrm{db}$ of total phenolic content (TPC), 29.20 and $18.25 \%$ of DPPH scavenging activity (DPPH), 185 and $255 \mu$ moles Trolox / $\mathrm{g} \mathrm{db}$ of CUPRAC, and 260 and $311 \mu$ mole $\mathrm{FeSO}_{4} / \mathrm{g} \mathrm{db}$ of FRAP, respectively. The values for TPC were low when compared to values reported in literature for leafy vegetables [16], however, the DPPH was within range. These are just some of the ways in which each plant differs from each other, no two plants are exactly the same, even the same specie but different cultivars are different, hence need for characterization. The effects of each of the pretreatments used on this study the TPC are as follows: 
There was increase with the BHW samples of up to about 1.73 and $1.325 \%$ at 50 and $40{ }^{\circ} \mathrm{C}$ of drying temperature respectively, similar to reports of Bamide et al. [16]. This must have been due to the composition of the TPC of this plant.

Some phenolic compounds were seen to appreciate on blanching while some depreciate at varying degrees on blanching. Irondi et al.[32] reported that every other phenolic compound identified in their study depreciated during blanching but quercetin increased by $245 \%$ and the least affected being the ellagic acid. Therefore, Justicia insularis may have been made of more of quercetin which may have been adversely affected at a higher temperature $\left(60{ }^{\circ} \mathrm{C}\right)$ of drying. The increase in TPC may also be due to the release of the phenolic acids that were bound in the cell walls of the leaves. The pretreatment that affected TPC most adversely was the BSW, it shows the highest loss of about $27.01 \%$ which may have been due to the fact that the salt solution may have reacted with the TPC to formed complex / other compounds making the TPC not available, making them sensitive to salt water. Jatropha tanjorensis followed a trend similar to that of Justicia insularis, with a maximum increase of $27.66 \%$ during BHW pretreatment and a highest loss of $10.76 \%$ during BSW pretreatment. UB samples showed the least loss, this must have due to fact the degradation wasn't much prior to drying. The little loss during UB may have been due to the drying temperature. The effects of temperature on TPC are seen to be minimal at $50{ }^{\circ} \mathrm{C}$, followed by $40{ }^{\circ} \mathrm{C}$ and maximum at $60{ }^{\circ} \mathrm{C}$. The DPPH scavenging activity was seen to increase for both leaves (Table 1 and 2) during the UB and BHW and worst during BSW. The increase in DPPH activity does not agree with the studies of Irondi et al. [32]. Several studies have reported the loss of DPPH during blanching due to leaching which is logical. However, this present study shows that every plant is unique. Report [17] has that blanching time and drying temperature could either reduce or enhance antioxidant activity in dried vegetables depending on the vegetable. The highest increase of CUPRAC (492 $\mu$ moles Trolox /g) in dried Justicia insularis samples was obtained at BHW60 ${ }^{\circ} \mathrm{C}$ while the least increase $(181 \mu$ moles Trolox $/ \mathrm{g} \mathrm{db})$ was obtained at BSW $40{ }^{\circ} \mathrm{C}$. In the same vein, CUPRAC in dried Jatropha tanjorensis leaves at BSW $40{ }^{\circ} \mathrm{C}$ recorded the least increase $(269 \mu$ moles Trolox $/ \mathrm{g}$ db) while the highest increase ( $412 \mu$ moles Trolox $/ \mathrm{g} \mathrm{db}$ ) was found at BHW60 ${ }^{\circ} \mathrm{C}$. Apart from that, FRAP in both dried vegetables increased as the drying temperature increased from $40{ }^{0} \mathrm{C}$ to $60{ }^{0} \mathrm{C}$ except at BHW where the content increased to $331 \mu$ mole $\mathrm{FeSO}_{4} / \mathrm{g}$ db initially and reduced infinitesimally from 355 to $353 \mu$ moles $\mathrm{FeSO}_{4} / \mathrm{g}$ db in dried Justicia insularis samples. The highest FRAP of 355 and $546 \mu$ moles $\mathrm{FeSO}_{4} / \mathrm{g} \mathrm{db}$ were obtained at BHW50 ${ }^{\circ} \mathrm{C}$ and BHW60 ${ }^{\circ} \mathrm{C}$, while the least amount of 234 and $300 \mu$ moles $\mathrm{FeSO}_{4} / \mathrm{g} \mathrm{db}$ were found at BSW $40{ }^{\circ} \mathrm{C}$, in both dried Justicia insularis and Jatropha tanjorensis leaves, respectively. Steam blanching of kaffir lime leaf was found to increase TPC and FRAP from $20.10 \pm 0.14$ to $22.18 \pm 0.06 \mathrm{mg} \mathrm{GAE} / \mathrm{g}$ and $447 \pm 9.01$ to $628 \pm 27.02 \mu$ mole $\mathrm{FeSO}_{4} / \mathrm{g}$ (Ratseewo et al., 2016). Blanching of Andrographis paniculata and heat-pump dehumidified drying at 40 to $60^{\circ} \mathrm{C}$ was observed to increase total phenolics [33]. Bamidele et al. [16] reported that 5 minutes blanching time was found to increase TPC of several vegetables (from 280.6 to $980.6 \mathrm{mg} \mathrm{GAE} / 100 \mathrm{~g} \mathrm{db}$ ) and other antioxidant activities (from 25.1 - $95.1 \mathrm{mg} \mathrm{GAE} / 100 \mathrm{~g} \mathrm{db}$ ). A combination of freeze/ microwave drying was observed to significantly increase the antioxidant activity (DPPH scavenging activity and FRAP) [13].

A study by Pierre et al., [20] showed an increase in total reducing power but decrease in DPPH scavenging activity of Moringa oleifer leaves after blanching and drying in an electric oven. 
Polyphenol content and DPPH of gurum seed oil were found to increase from 22.6 to $25.3 \mathrm{mg} \mathrm{GAE} / \mathrm{kg}$ oil and $59.2 \%$ to $64.7 \%$ after pretreatment, respectively [12]. The results of the present study are in line with similar reported studies [17, 34, 35].

However, by comparing both fresh leaves with pretreated and dried leaves, it is observed that all the mean values of TPC at different pretreatments and drying temperatures had statistical significant difference $\left(\mathrm{P}_{\mathrm{tab}}<0.05\right)$ for dried Justicia insularis leaves when compared with the fresh leaves. However, the pretreatment/ drying temperatures, for instance, UB50 ${ }^{\circ} \mathrm{C}$ and $60{ }^{\circ} \mathrm{C}$ and BSW $40{ }^{\circ} \mathrm{C}$ did not have any statistical significant difference on TPC when compared with the fresh leaves of Jatropha tanjorensis while the rest had statistical significant difference. Besides, all the mean values of DPPH in both vegetables had statistical significant mean differences. Furthermore, the mean values of CUPRAC in dried Justicia insularis and Jatropha tanjorensis leaves were not different from those ones obtained at BSW $40{ }^{\circ} \mathrm{C}$. Conversely, the mean values of FRAP in dried Justicia insularis and Jatropha tanjorensis leaves were all different from their corresponding fresh contents except those obtained at BSW $50{ }^{\circ} \mathrm{C}$ and $60{ }^{\circ} \mathrm{C}$, and BSW $40{ }^{\circ} \mathrm{C}$.

\section{Effect of Pretreatments and Drying Temperatures on Antioxidant Activity}

The effects of pretreatments and drying temperatures on antioxidant activity of Justicia insularis and Jatropha tanjorensis leaves are given on Table 2.

Table 2. Summary of ANOVA results showing the effect of pretreatments and drying temperatures on antioxidant activity of Justicia insularis and Jatropha tanjorensis leaves

\begin{tabular}{|c|c|c|c|c|c|}
\hline $\begin{array}{l}\text { Sample } \\
\text { Leaves }\end{array}$ & Antioxidant Activity & $\begin{array}{l}\text { Sources of } \\
\text { Variance }\end{array}$ & $\mathrm{R}^{2}$ & F-Value & $\begin{array}{l}\text { Sig. } \\
\left(\mathrm{P}_{\text {cal }}\right)\end{array}$ \\
\hline \multirow{4}{*}{$\begin{array}{l}\text { Justicia } \\
\text { insularis }\end{array}$} & $\begin{array}{c}\text { TPC } \\
(\mathrm{mg} \mathrm{GAE} \mathrm{/} \mathrm{g)}\end{array}$ & $\begin{array}{c}\mathrm{T} \\
\mathrm{P} \\
\mathrm{T} \times \mathrm{P}\end{array}$ & 1.000 & $\begin{array}{r}9060.7 * \\
1818.4 * \\
748.4 * \\
\end{array}$ & $\begin{array}{l}0.000 \\
0.000 \\
0.000 \\
\end{array}$ \\
\hline & $\begin{array}{c}\mathrm{DPPH} \\
(\%)\end{array}$ & $\begin{array}{c}\mathrm{T} \\
\mathrm{P} \\
\mathrm{T} \times \mathrm{P}\end{array}$ & 0.994 & $\begin{array}{l}543.0 * \\
109.0 * \\
72.97 *\end{array}$ & $\begin{array}{l}0.000 \\
0.000 \\
0.000 \\
\end{array}$ \\
\hline & $\begin{array}{r}\text { CUPRAC } \\
(\mu \text { moles Trolox } / g)\end{array}$ & $\begin{array}{c}\mathrm{T} \\
\mathrm{P} \\
\mathrm{T} \times \mathrm{P}\end{array}$ & 0.999 & $\begin{array}{r}5039.8^{*} \\
804.8^{*} \\
104.1 *\end{array}$ & $\begin{array}{l}0.000 \\
0.000 \\
0.000 \\
\end{array}$ \\
\hline & $\begin{array}{r}\text { FRAP } \\
\left(\mu \text { moles } \mathrm{FeSO}_{4} / \mathrm{g}\right)\end{array}$ & $\begin{array}{c}\mathrm{T} \\
\mathrm{P} \\
\mathrm{T} \times \mathrm{P}\end{array}$ & 0.995 & $\begin{array}{r}813.04 * \\
62.90 * \\
2.52\end{array}$ & $\begin{array}{l}0.000 \\
0.000 \\
0.115\end{array}$ \\
\hline \multirow{5}{*}{$\begin{array}{c}\text { Jatropha } \\
\text { tanjorensis }\end{array}$} & $\begin{array}{c}\text { TPC } \\
(\mathrm{mg} \mathrm{GAE} \mathrm{/} \mathrm{g)}\end{array}$ & $\begin{array}{c}\mathrm{T} \\
\mathrm{P} \\
\mathrm{T} \times \mathrm{P}\end{array}$ & 0.997 & $\begin{array}{r}1309.30 * \\
22.28 * \\
126.03 * \\
\end{array}$ & $\begin{array}{l}0.000 \\
0.000 \\
0.000 \\
\end{array}$ \\
\hline & $\begin{array}{l}\mathrm{DPPH} \\
(\%)\end{array}$ & $\begin{array}{c}\mathrm{T} \\
\mathrm{P} \\
\mathrm{T} \times \mathrm{P}\end{array}$ & 0.999 & $\begin{array}{r}3983.70^{*} \\
379.96^{*} \\
113.74^{*}\end{array}$ & $\begin{array}{l}0.000 \\
0.000 \\
0.000 \\
\end{array}$ \\
\hline & $\begin{array}{c}\text { CUPRAC } \\
(\mu \text { moles Trolox } / g)\end{array}$ & $\begin{array}{c}\mathrm{T} \\
\mathrm{P} \\
\mathrm{T} \times \mathrm{P}\end{array}$ & 0.996 & $\begin{array}{r}1190.81 * \\
21.76^{*} \\
7.01 *\end{array}$ & $\begin{array}{l}0.000 \\
0.002 \\
0.008 \\
\end{array}$ \\
\hline & \multirow{2}{*}{$\begin{array}{c}\text { FRAP } \\
\left(\mu \text { moles } \mathrm{FeSO}_{4} / \mathrm{g}\right)\end{array}$} & $\begin{array}{l}\mathrm{T} \\
\mathrm{P}\end{array}$ & 0.998 & $\begin{array}{r}691.02 * \\
1649.43 * \\
\end{array}$ & $\begin{array}{l}0.000 \\
0.000 \\
\end{array}$ \\
\hline & & $\mathrm{T} \times \mathrm{P}$ & & $132.34 *$ & 0.000 \\
\hline
\end{tabular}

Note: $\mathrm{R}^{2}=$ coefficient of determination, $\mathrm{F}$-value =variance ratio and

$\mathrm{P}_{\text {cal }}=$ calculated value of probability distribution. 
From Table 2, the overall effects of pretreatment $(\mathrm{P})$ and drying temperature $(\mathrm{T})$ on antioxidant activity of both dried vegetables is mostly notable with the values of $\mathrm{R}^{2}$ between $0.994-1.000$. The amount of distinctive influence of $\mathrm{P}$ and $\mathrm{T}$ revealed that $\mathrm{P}_{\text {cal }}$ $<0.05$ for all the antioxidant activities examined in both vegetables. Thus, F-values were all statistically significant. The interactive effect of $\mathrm{T} \times \mathrm{P}$ on antioxidant activities in both vegetables was also significant, except FRAP in dried Justicia insularis samples with $\mathrm{P}_{\text {cal }}=0.115$.

\section{Antinutrient Contents}

The summary and multiple comparisons of antinutrient content of fresh leaves with pretreated and dried leaves are presented in Table 3.

Table 3.Summary and multiple comparisons of antinutrient content of fresh leaves with pretreated and dried leaves of both Justicia insularis and Jatropha tanjorensis

\begin{tabular}{|c|c|c|c|c|c|c|c|c|c|}
\hline \multirow[b]{2}{*}{$P$} & \multirow[b]{2}{*}{ I } & \multicolumn{4}{|c|}{ Justicia insularis } & \multicolumn{4}{|c|}{ Jatropha tanjorensis } \\
\hline & & $\begin{array}{c}\text { Oxalate } \\
(\mathrm{mg} / 100 \mathrm{gdb})\end{array}$ & $\begin{array}{c}\mathrm{HCI} \\
(\mathrm{mg} / 100 \mathrm{gdb})\end{array}$ & $\begin{array}{c}\text { Tannin } \\
\text { (mg } / 100 \mathrm{gdb})\end{array}$ & \begin{tabular}{|c|}
$\begin{array}{c}\text { Phytate } \\
(\mathrm{mg} / 100 \mathrm{~g} \mathrm{db})\end{array}$ \\
\end{tabular} & $\begin{array}{c}\text { Oxalate } \\
(\mathrm{mg} / 100 \mathrm{gdb})\end{array}$ & $\begin{array}{c}\mathrm{HCl} \\
(\mathrm{mg} / 100 \mathrm{~g} d \mathrm{~b})\end{array}$ & $\begin{array}{c}\text { Tannin } \\
(\mathrm{mg} / 100 \mathrm{~g} \mathrm{db}) \\
\end{array}$ & $\begin{array}{c}\text { Phytate } \\
(\mathrm{mg} / 100 \mathrm{gdb})\end{array}$ \\
\hline FR & & $0.22 \pm 0.03^{2}$ & $0.65 \pm 0.04^{b}$ & $2.11 \pm 0.01^{6}$ & $4.35 \pm 0.04^{d}$ & $0.18 \pm 0.01^{2}$ & $0.10 \pm 0.01^{6}$ & $1.19 \pm 0.01^{!}$ & $1.24 \pm 0.04^{2}$ \\
\hline \multirow{3}{*}{ UB } & $40^{\circ} \mathrm{C}$ & $0.19 \pm 0.04^{2}$ & $0.62 \pm 0.01^{b}$ & $2.09 \pm 0.02^{6}$ & $4.22 \pm 0.01^{?}$ & $0.16 \pm 0.03^{3}$ & $0.08 \pm 0.02^{6}$ & $1.15 \pm 0.03^{?}$ & $1.11 \pm 0.03^{b}$ \\
\hline & $50^{\circ} \mathrm{C}$ & $0.17 \pm 0.02^{2}$ & $0.57 \pm 0.036$ & $2.04 \pm 0.03^{d}$ & $3.91 \pm 0.01^{\ddagger}$ & $0.14 \pm 0.02^{b}$ & $0.06 \pm 0.036$ & $1.13 \pm 0.01^{f}$ & $1.10 \pm 0.01^{6}$ \\
\hline & $60^{\circ} \mathrm{C}$ & $0.17 \pm 0.01^{13}$ & $0.45 \pm 0.03^{d}$ & $1.99 \pm 0.03^{\circ}$ & $4.01 \pm 0.15:$ & $0.13 \pm 0.01^{6}$ & $0.04 \pm 0.01^{d}$ & $0.92 \pm 0.018$ & $0.99 \pm 0.01^{d}$ \\
\hline \multirow{3}{*}{ BHW } & $40^{\circ} \mathrm{C}$ & $0.14 \pm 0.02^{b}$ & $0.41 \pm 0.019$ & $1.03 \pm 0.01^{f}$ & $3.33 \pm 0.47^{\mathrm{h}}$ & $0.09 \pm 0.01$ & $0.08 \pm 0.02^{\circ}$ & $0.93 \pm 0.02^{\mathrm{h}}$ & $0.86 \pm 0.03^{\circ}$ \\
\hline & $50^{\circ} \mathrm{C}$ & $0.09 \pm 0.011^{\circ}$ & $0.37 \pm 0.02^{9}$ & $1.02 \pm 0.018$ & $2.77 \pm 0.07$ & $0.07 \pm 0.019$ & $0.06 \pm 0.036$ & $1.03 \pm 0.03$ & $0.72 \pm 0.02^{f}$ \\
\hline & $60^{\circ} \mathrm{C}$ & $0.07 \pm 0.03$ & $0.34 \pm 0.038$ & $0.86 \pm 0.04^{\mathrm{h}}$ & $2.70 \pm 0.01 \mathrm{j}$ & $0.05 \pm 0.02^{f}$ & $0.05 \pm 0.011^{9}$ & $0.97 \pm 0.03$ & $0.63 \pm 0.028$ \\
\hline \multirow{3}{*}{ BSW } & $40^{\circ} \mathrm{C}$ & $0.21 \pm 0.01^{1}$ & $0.44 \pm 0.02^{2}$ & $1.12 \pm 0.03^{i}$ & $3.51 \pm 0.06^{k}$ & $0.15 \pm 0.04^{3}$ & $0.07 \pm 0.03^{6}$ & $0.81 \pm 0.01 k$ & $0.93 \pm 0.03^{h}$ \\
\hline & $50^{\circ} \mathrm{C}$ & $0.18 \pm 0.01^{3}$ & $0.31 \pm 0.01^{i}$ & $0.89 \pm 0.01 j$ & $3.48 \pm 0.08$ & $0.11 \pm 0.03 ?$ & $0.03 \pm 0.01^{\ddagger}$ & $0.76 \pm 0.02 !$ & $0.86 \pm 0.03$ \\
\hline & $60^{\circ} \mathrm{C}$ & $0.14 \pm 0.02$ & $0.33 \pm 0.011$ & $0.81 \pm 0.03^{\mathrm{k}}$ & $2.98 \pm 0.03^{\mathrm{m}}$ & $0.09 \pm 0.02^{\mathrm{h}}$ & $0.05 \pm 0.018$ & $0.96 \pm 0.01^{\mathrm{m}}$ & $0.85 \pm 0.015$ \\
\hline
\end{tabular}

Note: $\mathrm{P}=$ pretreatment, $\mathrm{T}=$ temperature $\left({ }^{0} \mathrm{C}\right), \mathrm{FR}=$ fresh sample, $\mathrm{UB}=$ un-blanched and dried sample, $\mathrm{BHW}=$ sample blanched in hot water and dried, and BSW $=$ sample blanched in salt water and dried. All data are the mean \pm standard deviation of duplicate. Mean with the same superscript in the same column are statistically the same as the fresh sample (ANOVA, $\mathrm{P}_{\mathrm{tab}}<0.05$, Dunnett t-test).

From Table 3, the fresh samples of Justicia insularis and Jatropha tanjorensis leaves were found to be 0.22 and $0.18 \mathrm{mg} / 100 \mathrm{~g} \mathrm{db}$ of oxalate, 0.65 and $0.10 \mathrm{mg} / 100 \mathrm{~g}$ $\mathrm{db}$ of HCN, 2.11 and $1.19 \mathrm{mg} / 100 \mathrm{~g} \mathrm{db}$ of tannin, and 4.35 and $1.24 \mathrm{mg} / 100 \mathrm{~g} \mathrm{db}$ of phytate, respectively. Notably, the concentrations of all the antinutrients in Justicia insularis leaves were higher than that of Jatropha tanjorensis leaves and were also reduced at increased drying temperature from $40{ }^{\circ} \mathrm{C}$ to $60{ }^{\circ} \mathrm{C}$. This study shows the reduction of antinutrients during all the pretreatment used in this study this is in agreement with some reported studies $[36,37,14,19,38]$ while others reported of increase in antinutrients at higher temperatures [18, 39]. However, oxalate contents in the fresh Justicia insularis and Jatropha tanjorensis leaves were found to reduce to minimal contents of $0.07 \mathrm{mg} / 100 \mathrm{~g} \mathrm{db}$ and $0.05 \mathrm{mg} / 100 \mathrm{~g} \mathrm{db}$, both at BHW60 ${ }^{0} \mathrm{C}$, respectively. Similarly, BSW $50{ }^{\circ} \mathrm{C}$ produced the least $\mathrm{HCN}$ content of 0.31 and $0.03 \mathrm{mg}$ / $100 \mathrm{~g} \mathrm{db}$ for Justicia insularis and Jatropha tanjorensis leaves, respectively. 
The minimum tannin contents of 0.81 and $0.76 \mathrm{mg} / 100 \mathrm{~g} \mathrm{db}$ were found at BSW60 ${ }^{0} \mathrm{C}$ and BSW50 ${ }^{0} \mathrm{C}$ for Justicia insularis and Jatropha tanjorensis leaves, respectively. The lowest phytate contents of 2.70 and $0.63 \mathrm{mg} / 100 \mathrm{~g} \mathrm{db}$ were obtained at BHW $60{ }^{\circ} \mathrm{C}$ for both Justicia insularis and Jatropha tanjorensis leaves, respectively. Generally, the reduction in antinutrients may be due to leaching during duration blanching. It was observed that $\mathrm{BHW} 60{ }^{0} \mathrm{C}$ favored reduction of oxalate and phytate contents while BSW50 ${ }^{\circ} \mathrm{C}$ drastically reduced $\mathrm{HCN}$ and tannin contents. However, by comparing both fresh leaves with pretreated and dried leaves, it is observed that the mean values of oxalate content of Justicia insularis leaves at BHW40 ${ }^{\circ} \mathrm{C}$, BHW50 ${ }^{0} \mathrm{C}$ and BSW $60{ }^{0} \mathrm{C}$ were statistically different from that of the fresh sample at $\mathrm{P}_{\text {tab }}<0.05$ when compared while the rest with the same superscript in the same column did not have any statistical significant difference. Also, the mean value of oxalate content of fresh Jatropha tanjorensis leaves was not different from those ones obtained at UB $40{ }^{0} \mathrm{C}$ and BSW 40 ${ }^{0} \mathrm{C}$. Similarly, the fresh HCN content of Justicia insularis leaves was the same as the one obtained at UB $40{ }^{\circ} \mathrm{C}$. The rest showed statistical significant differences. However, all the mean values of $\mathrm{HCN}$ content of dried Jatropha tanjorensis leaves obtained at UB40 ${ }^{0} \mathrm{C}$, UB50 ${ }^{\circ} \mathrm{C}$, BHW40 ${ }^{0} \mathrm{C}$, BHW50 ${ }^{\circ} \mathrm{C}$ and BSW40 ${ }^{\circ} \mathrm{C}$ were not significantly different from that of the fresh sample. Besides, the mean values of tannin content in dried Justicia insularis and Jatropha tanjorensis leaves obtained at UB40 ${ }^{0} \mathrm{C}$ were not different from their corresponding fresh contents while the rest recorded statistical significant mean differences. Furthermore, the mean values of phytate content in dried Justicia insularis and Jatropha tanjorensis leaves were all different from their corresponding fresh contents. It can be deduced that pretreatment and drying temperature could affect to some extent the antinutrients present in both vegetables under investigation.

\section{Effect of Pretreatments and Drying Temperatures on Antinutrient Contents}

The effects of pretreatments and drying temperatures on antinutrient contents of Justicia insularis and Jatropha tanjorensis leaves are given on Table 4 and Table 5.

Table 4. Summary of ANOVA results showing the effect of pretreatments and drying temperatures on antinutrient contents of Justicia insularis leaves

\begin{tabular}{|c|c|c|c|c|c|}
\hline Sample Leaves & $\begin{array}{l}\text { Antinutrient } \\
\text { Content }\end{array}$ & $\begin{array}{c}\text { Sources of } \\
\text { Variance }\end{array}$ & $\mathrm{R}^{2}$ & F-Value & $\begin{array}{c}\text { Sig. } \\
\left(\mathrm{P}_{\mathrm{cal}}\right)\end{array}$ \\
\hline \multirow{5}{*}{$\begin{array}{l}\text { Justicia } \\
\text { insularis }\end{array}$} & $\begin{array}{c}\text { Oxalate } \\
(\mathrm{mg} / 100 \mathrm{~g})\end{array}$ & $\begin{array}{c}\mathrm{T} \\
\mathrm{P} \\
\mathrm{T} \times \mathrm{P}\end{array}$ & 0.896 & $\begin{array}{r}9.148 * \\
26.704 * \\
1.41\end{array}$ & $\begin{array}{l}0.007 \\
0.000 \\
0.307\end{array}$ \\
\hline & $\begin{array}{c}\mathrm{HCN} \\
(\mathrm{mg} / 100 \mathrm{~g})\end{array}$ & $\begin{array}{c}\mathrm{T} \\
\mathrm{P} \\
\mathrm{T} \times \mathrm{P}\end{array}$ & 0.979 & $\begin{array}{r}47.54 * \\
152.54 * \\
7.10 *\end{array}$ & $\begin{array}{l}0.000 \\
0.000 \\
0.007\end{array}$ \\
\hline & \multirow{2}{*}{$\begin{array}{c}\text { Tannin } \\
(\mathrm{mg} / 100 \mathrm{~g})\end{array}$} & $\begin{array}{l}\mathrm{T} \\
\mathrm{P}\end{array}$ & 0.999 & $\begin{array}{r}95.4^{*} \\
4083.4^{*}\end{array}$ & $\begin{array}{l}0.000 \\
0.000\end{array}$ \\
\hline & & $\mathrm{T} \times \mathrm{P}$ & & $17.69^{*}$ & 0.000 \\
\hline & $\begin{array}{c}\text { Phytate } \\
(\mathrm{mg} / 100 \mathrm{~g})\end{array}$ & $\begin{array}{c}\mathrm{T} \\
\mathrm{P} \\
\mathrm{T} \times \mathrm{P}\end{array}$ & 0.949 & $\begin{array}{r}11.49^{*} \\
67.10^{*} \\
2.47\end{array}$ & $\begin{array}{l}0.003 \\
0.000 \\
0.120\end{array}$ \\
\hline
\end{tabular}


Table 5. Summary of ANOVA results showing the effect of pretreatments and drying temperatures on antinutrient contents of Jatropha tanjorensis leaves

\begin{tabular}{|c|c|c|c|c|c|}
\hline \multirow{4}{*}{$\begin{array}{c}\text { Jatropha } \\
\text { tanjorensis }\end{array}$} & $\begin{array}{c}\text { Oxalate } \\
(\mathrm{mg} / 100 \mathrm{~g})\end{array}$ & $\begin{array}{c}\mathrm{T} \\
\mathrm{P} \\
\mathrm{T} \times \mathrm{P}\end{array}$ & 0.826 & $\begin{array}{r}5.86^{*} \\
14.86^{*} \\
0.29\end{array}$ & $\begin{array}{l}0.023 \\
0.001 \\
0.876\end{array}$ \\
\hline & $\begin{array}{c}\mathrm{HCN} \\
(\mathrm{mg} / 100 \mathrm{~g})\end{array}$ & $\begin{array}{c}\mathrm{T} \\
\mathrm{P} \\
\mathrm{T} \times \mathrm{P}\end{array}$ & 0.531 & $\begin{array}{l}3.05 \\
0.66 \\
0.70\end{array}$ & $\begin{array}{l}0.097 \\
0.541 \\
0.613\end{array}$ \\
\hline & $\begin{array}{c}\text { Tannin } \\
(\mathrm{mg} / 100 \mathrm{~g})\end{array}$ & $\begin{array}{c}\mathrm{T} \\
\mathrm{P} \\
\mathrm{T} \times \mathrm{P} \\
\end{array}$ & 0.986 & $\begin{array}{r}1.38 \\
172.60 * \\
67.60^{*} \\
\end{array}$ & $\begin{array}{l}0.300 \\
0.000 \\
0.000 \\
\end{array}$ \\
\hline & $\begin{array}{l}\text { Phytate } \\
(\mathrm{mg} / 100 \mathrm{~g})\end{array}$ & $\begin{array}{c}\mathrm{T} \\
\mathrm{P} \\
\mathrm{T} \times \mathrm{P}\end{array}$ & 0.989 & $\begin{array}{r}62.50^{*} \\
327.84^{*} \\
8.80^{*}\end{array}$ & $\begin{array}{l}0.000 \\
0.000 \\
0.004 \\
\end{array}$ \\
\hline
\end{tabular}

From Table 4 and Table 5, the overall effect of pretreatment (P) and drying temperature $(\mathrm{T})$ on antinutrients of both dried vegetables is judged by the values of $\mathrm{R}^{2}$, which ranged from 0.531 to 0.999 .

However, the gross effect of $\mathrm{P}$ and $\mathrm{T}$ on HCN content of Jatropha tanjorensis leaves was statistically insignificant, since $\mathrm{R}^{2}=0.531$ (quite less than 1.00). This implies that the combination of $\mathrm{P}$ and $\mathrm{T}$ may likely have minute reduction in $\mathrm{HCN}$ content of dried Jatropha tanjorensis leaves. Besides, the amount of distinctive effect of $\mathrm{P}$ and $\mathrm{T}$ revealed that $\mathrm{P}_{\text {cal }}<0.05$, thus, F-values were statistically significant for all the antinutrients examined in both vegetables except tannin and HCN contents in Jatropha tanjorensis leaves. This means that within the drying temperature of $40{ }^{0} \mathrm{C}-60{ }^{0} \mathrm{C}$, variation in tannin and $\mathrm{HCN}$ contents in Jatropha tanjorensis leaves may be infinitesimal. The interactive effect $(\mathrm{T} \times \mathrm{P})$ on antinutrients in both vegetables was also significant, except oxalate and phytate contents in dried Justicia insularis samples and oxalate content in dried Jatropha tanjorensis leaves with $\mathrm{P}_{\text {cal }}>0.05$. It therefore means that pretreated samples using appropriate method and dried at optimum temperature could possibly reduce these antinutrients.

\section{CONCLUSIONS}

This study was carried out to evaluate the effects of processing temperature and pretreatments on antioxidant and antinutrient content of Justicia insularis and Jatropha tanjorensis leaves. BHW pretreatment between $50^{\circ} \mathrm{C}$ and $60^{\circ} \mathrm{C}$ was found to increase the antioxidant activity in both vegetables. BHW at $60{ }^{\circ} \mathrm{C}$ was able to reduce oxalate and phytate contents to minimal level while BSW at $50{ }^{\circ} \mathrm{C}$ drastically decreased $\mathrm{HCN}$ and tannin contents. However, the overall, individualistic, and interactive effects of $\mathrm{P}$ and $\mathrm{T}$ had significant $\left(\mathrm{P}_{\text {cal }}<0.05\right)$ influence on majority of antioxidant activity and antinutrient contents in both vegetables. 
It could therefore be concluded that Blanching Justicia insularis and Jatropha tanjorensis leaves using hot water at $95^{\circ} \mathrm{C}$ for 2 mins and drying within the range of temperature in this study could possibly increase the antioxidant activity and also reduce antinutrients to some level.

\section{REFERENCES}

[1] Vaclavik, V. and Christian, W. E. (2008). Essential of Food Science. New York: Springer Science Business Media.

[2] Bazzano, L. A., He, J., Ogden, L. G., Loria, C. M., Vupputuri, S., Myers, L., and Whelton, P. K. (2002). Fruit and vegetable intake and risk of cardiovascular disease in US adults: The First National Health and Nutrition Examination Survey Epidemiologic Follow-up Study. The American Journal of Clinical Nutrition, 76(1): pp. 93 -99.

[3] Enoch, G. A., Magaret, W. P. and Francoise, A. K. (2009). Traditional vegetables in Benin: Diversity, distribution, ecology, agronomy and utilization. Darwin Initiative Project 15/003 \& International Foundation of Science Project T/3701 Draft, 94 -95.

[4] Danborno, A. M., Tarfa, F., Toryila, J. E., Awheela, E. U. and Shekarau, V. T. (2019). The effects of Jatropha tanjorensis aqueous leaf extract on haematological parameters in Wistar rats. J. of African Association of Physiological Sciences, 7 (2): pp. 133 -137.

[5] Ochulor, O. C., Njoku, O. U., Uroko, R. I. and Egba, S. I. (2018). Nutritional composition of Jatropha tanjorensis leaves and effects of its aqueous extract on carbon tetrachloride induced oxidative stress in maleWistar albino rats. Biomedical Research, 29 (19): pp. 3569 - 3576.

[6] Adeyemi , O. T. and Babatubde, O. (2014). Chemical composition and antioxidant capacity of leaf extract of Justicia insularis. International Journal of Physical Science, 9 (20): pp. 454-458.

[7] Tamizhazhagan, V. and Pugazhendy, K. (2017). Ethnobotanical and phytopharmacological review of Pisonia alba. Asian Journal of Pharmaceutical and Clinical Research, 10 (5): pp. $69-71$

[8] Amel, O. H., Malek, B. H., Hiechem, B. J., Ali, L., Mahjoub, A. and Boulbaba, S. (2013). Antioxidant and anti-acetyl cholinesterase activities of extract from Rapistrum rugosum in Tunisia. Asian Pacific Journal of Tropical Disease, 3 (5): pp. 367-374.

[9] Satish, B.N. and Dilipkumar, P. (2015). Free radicals, natural antioxidants, and their reaction mechanisms. RSC Advances, 5: pp. 27986-28006.

[10] Josh, A. (2020). Available through https://draxe.com/nutrition/antinutrients/

[11] Badwaik, L.S., Gautam, G. and Deka, S.C. (2015). Influence of blanching on antioxidant, nutritional and physical properties of bamboo shoot. Journal of Agricultural Sciences - Sri Lanka, 10(3): pp. 140-150.

[12] Karrar, E., Sheth, S., Wei, W. and Wang, X. (2020). Effect of microwave heating on lipid composition, oxidative stability, color value, chemical properties, and antioxidant activity of gurum (Citrulluslanatus var. Colocynthoide) seed oil. Biocatalysis and Agricultural Biotechnology, 23: pp. 1-7

[13] Li, L., Zhang, M., Chitrakar, B. and Jiang, H. (2020). Effect of combined drying method on phytochemical components, antioxidant capacity and hygroscopicity of Huyou (Citrus changshanensis) fruit. LWT- Food Science and Technology, 123, 109102. doi:10.1016/j.1wt.2020.109102 
[14] Alagbaoso, S. O., Nwosu, J. N., Agunwa, I. M., Njoku, N. E., Akajiaku, L. O. and Eluchie, C. N. (2016). Effect of some thermal processing techniques on the antinutritional factors of Canavalia plagiosperma piper seeds. American Journal of Food Science and Technology, 4 (1): pp. 7- 13

[15] Arif, M. and Zeb, A. (2020). Effects of different cooking techniques on bioactive contents of leafy vegetables. I. Journal of Gastronomy and Food Science, 22: pp. 1- 8.

[16] Bamidele, O. P., Fasogbon, M.B., Adebowale, O. J. and Adeyanju, A. A. (2017) Effect of blanching time on total phenolic, antioxidant activities and mineral content of selected green leafy vegetables. Current J. of Applied Science and Technology, 24 (4): pp.1-8

[17] Hassan, M. M. and Joshi, N. (2020). Hydrothermal effects on physicochemical, sensory attributes, vitamin $\mathrm{C}$, and antioxidant activity of frozen immature Dolichos lablab. Heliyon, 6: pp. 1-7.

[18] Nguyen, P. M., Van, T. P., Thach, K. H., Vuong, T. S. and Lam, T. S. (2019). Effect of blanching and drying to production of dried herbal tea from Pouzolzia zeylanica. Journal Pharmaceutical Science \& Research, 11(4): pp. 1437-1440

[19] Okorie, S. U. and Nwanekezi, E. C. (2014). Evaluation of proximate composition and antinutrition factor of Cyperus esculentus (Tiger nut) as influence by boiling. ISOR Journal of Environmental Science, Toxicology and Food technology, 8 (7): pp. 70-73.

[20] Pierre, N., Edith, N. F. and Carl, M. F. (2017). The effect of steam blanching and drying method on nutrients, phytochemicals and antioxidant activity of Moringa (Moringa oleifera L.) leaves. Am. J.of Food Science and Technology, 5: pp. 53 - 60.

[21] Ratseewo, J., Tangkhawanit, E., Meeso, N., Kaewseejan, N. and Siriamornpun, S. (2016). Changes in antioxidant properties and volatile compounds of kaffir lime leaf as affected by cooking processes. Int. Food Research Journal, 23 (1): pp. 188-196.

[22] Ikrang, E., Okoko, J., Obot, M., and Akubuo, C. (2014). Modeling of thin layer drying kinetics of salted fish fillets (Tilapia Zilli) in a direct passive solar dyer. IOSR J. of Environ. Science, Toxicology and Food Technology, 8, Issue 1 ver IV: pp. 16-24.

[23] Omolola, A. O., Kapila, P. F. and Silungwe (2018). Mathematical modeling of drying characteristics of Jews mallow (Corchorus olitorius) leaves. Information Processing in Agriculture. doi.org/10.1016/j.inpa.2018.08.003

[24] Makkar, H. P. S., Siddhuraju, P. and Becker, K. (2007). Plant Secondary Metabolites. Totowa, New Jersey: Humana Press.

[25] Bakar, M. F. A., Mohamed, M. Rahmat, A. and Fry, J. (2009). Phytochemicals and antioxidant activity of different parts of bambangan (Mangifera pajang) and tarap (Artocarpus odoratissimus). Food Chemistry, 113: pp. 479-483.

[26] Gulluce, M., Sahin, F., Sokmen, M., Ozer, H., Daferera, D., Sokmen, A., Polissiou, M., Adiguzel, A. and Ozkan, H. (2007). Antimicrobial and antioxidant properties of the essential oils and methanol extract from Mentha longifolia L. ssp. Food Chemistry, 103: pp. 1449-1456.

[27] Sethi, S., Joshi, A., Arora, B., Bhowmik, A., Sharma, R. R. and Kumar, P. (2020) Significance of FRAP, DPPH, and CUPRAC assays for antioxidant activity determination in apple fruit extracts. European Food Research and Technology. Doi:10.1007/s00217-020-03432-z

[28] Butsat, S. and Siriamornpun, S. (2010). Antioxidant capacities and phenolic compounds of the husk, bran and endosperm of Thai rice. Food Chemistry, 119: pp.606-613.

[29] AOAC (Association of Official and Analytical Chemists) (2012). Official Methods of Analysis. 19th Edition, Ass.of Official and Analytical Chemists, Washington D.C.

[30] Nwokoro, O., Ogbonna, J. C. and Okpala, G. N. (2009). Simple picrate method for the determination of cyanide in cassava flour. Bio-Research, 7(2): pp. $502-504$. 
[31] Makkar, H. P. S., Blummel, M., Borowy, N. K. and Becker, K. (1993). Gravimetric determination of tannins and their correlations with chemical and protein precipitation methods. Journal of the Science of Food and Agriculture, 61: pp.161-165.

[32] Irondi, E.A., Akintunde, J K., Agboola, S. O., Boligon, A. A., and Athayde, M. L. (2016). Blanching influences the phenolics composition, antioxidant activity, and inhibitory effect of Adansonia digitata leaves extract on $\alpha$-amylase, $\alpha$-glucosidase, and aldose reductase. Food Science and Nutrition. doi: 10.1002/fsn3.38

[33] Tummanichanont, C., Phoungchandang, S. and Srzednicki, G. (2017). Effects of pretreatment and drying methods on drying characteristics and quality attributes of Andrographis paniculata. Journal of Food Processing and Preservation, 41(6), e13310. doi:10.1111/jfpp.13310

[34] Isaac, O. N., Willis, O. O., Samuel, I. and Jane, A. (2019). Effect of pretreatments prior to drying on antioxidant properties of dried mango slices. Scientific African, https://doi.org/10.1016/j.sciaf.2019.e00148.

[35] Wickramasinghe, Y. W. H., Wickramasinghe, I. and Wijesekara, I. (2020). Effect of steam blanching, dehydration temperature and time, on the sensory and nutritional properties of a herbal tea developed from Moringa oleifera Leaves. International Journal of Food Science, Vol. 2020: pp.1 -11. https://doi.org/10.1155/2020/5376280

[36] Sahadi, D. I., Ira, D. R. and Amanda, F. (2016). The influence of drying temperature on chemical components of herbal tea leaves (Spondias dulcis, soland). Researchgate: pp. 1 -7. https://www.researchgate.net/publication/311218525

[37] Somsub, W., Kongkachuichai, R., Sungpuag, P. and Charoensiri, R. (2008). Effects of three conventional cooking methods on vitamin $\mathrm{C}$, tannin, myo-inositol phosphates contents in selected Thai vegetables. Journal of Food Composition and Analysis, 21(2):pp. 187-197. https://doi.org/10.1016/j.jfca.2007.08.002

[38] Arias-Rico, J., Macías-León, F. J., Alanís-García, E., Cruz-Cansino, N. del S., Jaramillo-Morales, O. A., Barrera-Gálvez, R. and Ramírez-Moreno, E. (2020). Study of edible plants: Effects of boiling on nutritional, antioxidant, and physicochemical properties. Foods, 9 (5): pp. 599. doi:10.3390/foods9050599

[39] Olabode, Z., Akanbi, C.T., Olunlade, B. and Adeola, A. A. (2015). Effects of drying temperature on the nutrients of moringa (Moringa oleifera) leaves and sensory attributes of dried leaves infusion. Direct Research Journal of Agriculture and Food Science, 3 (5): pp. 117 - 122.

\title{
EFEKTI PREDTRETIRANJA I TEMPERATURE SUŠENJA NA ANTIOKSIDANTE I ANTINUTRIJENTE LISTA Justicia insularis I Jatropha tanjorensis
}

\author{
Akpan Mfrekemfon Godswil ${ }^{1}$, Assian Ubong Edet ${ }^{1}$, Ikrang Elijah Gorge ${ }^{1}$ \\ ${ }^{I}$ Department of Agricultural and Food Engineering, Faculty of Engineering, \\ University of Uyo, Uyo, P. M. B. 1017, Akwa Ibom State, Nigeria
}

Sažetak: Obrada posle berbe povrća može uticati na antioksidante i antinutrijente listova povrća. Ova studija sprovedena je da se proceni efekat predtretmana (P) i temperatura sušenja (T) na antioksidante i antinutrijente listova povrća Justicia insularis i Jatropha tanjorensis. Pripremljene su četiri grupe uzoraka: sveži uzorak (FR), neblanširani i osušeni uzorak (UB), uzorak blanširan u vrućoj vodi i osušen (BHV) i uzorak blanširan u slanoj vodi i osušen (BSV). 
Sušenje listova povrća je izvedeno na temperaturama od $40^{\circ} \mathrm{C}, 50^{\circ} \mathrm{C}$ i $60^{\circ} \mathrm{C}$ u peći sa toplim vazduhom. Određeni su sadržaji antioksidanta i antinutrijenta u uzorku. Prikupljeni podaci su analizirani dvostrukom Analizom varijanse (ANOVA), I Dunnett t-testom na nivou verovatnoće od $5 \%$.

$\mathrm{Na}$ osnovu rezultata, $\mathrm{BHV}$ između $50^{\circ} \mathrm{C}$ i $60^{\circ} \mathrm{C}$ povećao je antioksidativnu aktivnost u oba varijeteta listova povrća. BHV na $60^{\circ} \mathrm{C}$ je imao manji sadržaj oksalata i fitata na razumni nivo, dok je $\mathrm{BSV} 50^{\circ} \mathrm{C}$ drastično smanjio sadržaj hidrogen cijanida i tanina . Međutim, ukupni, individualni i interaktivni efekti $\mathrm{P}$ i T imaju značajan $\left(\mathrm{P}_{\mathrm{cal}}<0,05\right)$ uticaj na većinu antioksidativne aktivnosti i sadržaja antinutrijenata $u$ oba ispitivana varijeteta povrća.

Ključne reči: Justicia insularis, Jatropha tanjorensis, predtretman, temperatura sušenja, antioksidanti, antinutrijenti

Prijavljen:

Submitted: 15.07.2021.

Ispravljen:

Revised: 20.07.2021.

Prihvaćen:

Accepted: 23.07.2021. 